\title{
Molar and Incisor Hypomineralization
}

\author{
Basim Almulhim' \\ 'Department of Preventive Dental Sciences, College of Dentistry, Majmaah University, Al-Majmaah, Saudi Arabia.
}

\section{ABSTRACT}

Molar and incisor hypomineralization is a developmental defect that is systemic in origin that affects one or more than one permanent first molars, and is often associated with permanent incisors. It is usually characterized by well demarcated opacities and qualitative enamel defects caused by decreased inorganic enamel components, and reduced mineralization. It can cause esthetic, functional, psychological, and behavioral problems in children. Its reported prevalence varies widely, from $2.5 \%$ to $40.2 \%$. Multiple aspects of dental treatment for it are challenging, such as behavior management, difficulty in achieving adequate local anesthesia, tooth hypersensitivity, and retention of restorations. This review discusses the most important considerations pertaining to its prevalence, severity, etiology, differential diagnosis, and some of the challenges and treatment modalities applicable in young patients. Data is collected from PubMed, Medline, and Embase databases.

Keywords: developmental defects; enamel hypoplasia; hypersensitivity; molar incisor hypomineralization.

\section{INTRODUCTION}

Molar and incisor hypomineralization $(\mathrm{MIH})$ is a systemic developmental defect affecting one or more permanent first molars (PFMs) and is frequently associated with permanent incisors. It is characterized by well demarcated opacities; qualitative defects of enamel caused by reduced inorganic enamel components; and reduced mineralization that can cause esthetic, functional, psychological, and behavioral problems in children. ${ }^{1-3}$ Usually, no other permanent teeth are involved.

Studies of the prevalence of MIH have shown variable results, with reported rates ranging from $2.5 \%$ to $40.2 \%{ }^{4-6}$ According to one study, the condition affected one in six children in the general population. ${ }^{7}$ As the PFMs are the first permanent tooth to erupt, they may exhibit rapid caries progression and be more prone to break down than teeth that erupt later. ${ }^{1-8}$ The dental management of $\mathrm{MIH}$ presents substantial challenges in numerous respects. ${ }^{9-11}$

This review discusses the most important aspects of $\mathrm{MIH}$, including factors pertaining to its prevalence, etiology, severity, differential diagnosis, and treatment modalities in young patients.

\section{ETIOLOGY}

To date, the causative mechanism of $\mathrm{MIH}$ remains unknown, but some authors consider it as multifactorial. ${ }^{1,10,12-14}$ Congenital and environmental factors have been proposed, ${ }^{1,10,12,14-17}$ as has the involvement of systemic conditions, such as respiratory tract infections. Other suggested causes include childhood diseases, ${ }^{1,2,12}$ particularly those requiring the extended use of antibiotics, ${ }^{1,16}$ as well as other medical conditions that may influence or disrupt amelogenesis during the early development of the PFMs. ${ }^{16}$ In one study, the environmental pollutants polychlorinated dibenzo-p-dioxins/dibenzofurans were associated with $\mathrm{MIH},{ }^{18}$ although notably, in a more recent study, no such significant association was found. ${ }^{19}$ Exposure to contaminants as polychlorinated biphenyls is associated with an increased risk of $\mathrm{MIH} .{ }^{17,20}$ The causes of molar and incisor hypomineralization (Table 1).

Correspondence: Dr. Basim Almulhim, Department of Preventive Dental Sciences, College of Dentistry, Majmaah University, Al-Majmaah, Saudi Arabia. Email: b.almulhim@mu.edu.sa, Phone: +966500222665 . 


\begin{tabular}{|c|c|}
\hline Congenital & Hereditary factors that are involved in the etiology of MIH may interact with systemic factors ${ }^{1,20,21}$ \\
\hline $\begin{array}{l}\text { Environmental } \\
\text { Factors }\end{array}$ & Exposure to pollutants (dioxins) during third trimester and/or first three years of life $1,10,12,14-17,19-21$ \\
\hline $\begin{array}{l}\text { Systemic } \\
\text { Conditions }\end{array}$ & $\begin{array}{l}\text { Disruption of amelogenesis during early maturation }{ }^{2} \text { caused by: } \\
\text { Respiratory tract infections } \mathbf{1}^{1,2,13} \\
\text { Perinatal complications } \\
\text { Oxygen deprivation } 1,2,13,15,16 \\
\text { Low birth weight } 1,2,13,15,16 \\
\text { Calcium and phosphate metabolism disorders } \\
\text { Recurrent childhood illnesses } \\
\text { Prolonged use of antibiotics }{ }^{1,17}, 13,15,16 \\
\text { Long-term breast feeding }\end{array}$ \\
\hline
\end{tabular}

\section{SEVERITY}

A severity scale for individual teeth is defined that categorizes $\mathrm{MIH}$ as mild, moderate, or severe (Table 2). ${ }^{21}$

\begin{tabular}{|c|c|c|c|}
\hline & Mild & Moderate & Severe \\
\hline $\begin{array}{l}\text { Crown } \\
\text { appearance }\end{array}$ & $\begin{array}{l}\text { Demarcated opacities* not } \\
\text { involving the load-bearing } \\
\text { area of the molars }\end{array}$ & Intact atypical restorationt & $\begin{array}{l}\text { Post-eruptive enamel } \\
\text { breakdown } \neq\end{array}$ \\
\hline Enamel loss & Isolated opacities & $\begin{array}{l}\text { Involvement of occlusal or incisal } 1 / 3 \text { of } \\
\text { teeth, but without initial post-eruptive } \\
\text { enamel breakdown }\end{array}$ & $\begin{array}{l}\text { Post-eruptive enamel } \\
\text { breakdown, usually } \\
\text { severe }\end{array}$ \\
\hline Caries & No associated caries & $\begin{array}{l}\text { Caries limited to one or two surfaces and } \\
\text { without cuspal involvement, and possible } \\
\text { post-eruptive enamel breakdown }\end{array}$ & $\begin{array}{l}\text { Substantial } \\
\text { progression of caries }\end{array}$ \\
\hline Sensitivity & Normal dental sensitivity & $\begin{array}{l}\text { Child usually exhibits normal dental } \\
\text { sensitivity }\end{array}$ & $\begin{array}{l}\text { A history of dental } \\
\text { sensitivity }\end{array}$ \\
\hline Esthetics & No parental concerns & Parental concerns & Parental concerns \\
\hline
\end{tabular}

*A demarcated defect presenting as a change in enamel translucency; variable in degree. Enamel is usually of normal thickness and has a smooth surface. It can be yellow, brown, or white in color.

†Restorations on the posterior teeth that extends to the buccal, palatal, or lingual side. Some opacities at the borders of the restorations are common. Facial restorations not related to dental trauma are evident on the anterior teeth.

$¥ A$ defect which indicates loss of tooth surface post eruption. Pre-existing demarcated opacities are often associated with enamel loss.

The Würzburg MIH workgroup recently proposed the MIH Treatment Need Index (MIHTNI), which can be used for diagnosing and treating $\mathrm{MIH}$ in individual teeth. ${ }^{22}$ The MIHTNI score is usually not dependent on the degree of destruction, but if the tooth is hypersensitive, it is considered. ${ }^{22}$ The index values of molar and incisor hypo-mineralization (Table 3 ).

\begin{tabular}{|c|c|}
\hline $\begin{array}{l}\text { Table } \\
\text { treatm }\end{array}$ & $\begin{array}{l}\text { 3. Molar and incisor hypomineralization } \\
\text { ent need index. } .^{22}\end{array}$ \\
\hline Score & Definition \\
\hline 0 & No MIH \\
\hline 1 & $\begin{array}{l}\text { MIH without hypersensitivity and without } \\
\text { defect }\end{array}$ \\
\hline 2 & MIH without hypersensitivity, but with defect \\
\hline $2 a$ & $<1 / 3$ defect extension \\
\hline $2 b$ & $>1 / 3$, but $<2 / 3$ defect extension \\
\hline 2c & $\begin{array}{l}>2 / 3 \text { defect extension and/or defect close } \\
\text { to the pulp requiring extraction or atypical } \\
\text { restoration }\end{array}$ \\
\hline 3 & MIH with hypersensitivity, but without defect \\
\hline 4 & MIH with hypersensitivity and with defect \\
\hline $4 a$ & $<1 / 3$ defect extension \\
\hline $4 b$ & $>1 / 3$, but $<2 / 3$ defect extension \\
\hline 4c & $\begin{array}{l}>2 / 3 \text { defect extension and/or defect close } \\
\text { to the pulp requiring extraction or atypical } \\
\text { restoration }\end{array}$ \\
\hline
\end{tabular}




\section{DIAGNOSIS}

Diagnosis of $\mathrm{MIH}$ can be challenging, and the condition may be confused with other hereditary conditions, particularly developmental enamel defects as amelogenesis imperfecta, fluorosis, white spot lesions, enamel hypoplasia, and traumatic hypomineralization. The criteria for diagnosis of $\mathrm{MIH}$ are based on the clinical findings of well demarcated opacities, breakdown that is post eruptive, atypical restorations, and PFM extraction for reasons suggestive of $\mathrm{MIH} .^{1,3,21,23-30}$ The factors that should be considered in the differential diagnosis of MIH (Table 4).

\begin{tabular}{|ll|}
\hline Table 4. Differential diagnosis of MIH. \\
\hline Molar and incisor & White, creamy, or yellow-brown opacities \\
& Affects one or more than one first permanent molars and often associated with \\
& permanent incisors, while other teeth are not affected \\
& Lesion > $1 \mathrm{~mm}$ \\
& Asymmetrical pattern \\
& Caries often present \\
& Post-eruptive enamel breakdown \\
Amelogenesis imperfecta ${ }^{1,23-26,29,30}$ & Often with a family history \\
& Affects primary and permanent dentitions \\
& Possibility of enamel resorption and ankylosis \\
& Possibility of anterior open bite \\
& Possibility for agenesis of second molars \\
Fluorosis & With a history of fluoride intake during tooth development \\
& Primary dentition is usually not affected, but all permanent teeth usually tend to \\
& be involved \\
White spot lesions ${ }^{1,3,21,30}$ & Symmetrical and bilateral pattern \\
Traumatic & Caries resistant \\
hypomineralization $^{1,3,21,30}$ & Occur in the cervical areas of teeth because of plaque accumulation in this area \\
& History of injury to the affected deciduous tooth \\
& Often limited to one tooth \\
& Asymmetrical pattern \\
\hline
\end{tabular}

\section{CHALLENGES AND CLINICAL PROBLEMS ASSOCIATED WITH MIH}

Tooth sensitivity can cause a child to neglect oral hygiene, resulting in susceptibility to caries. There is a need for early emphasis on preventive measures to avoid post-eruptive enamel breakdown. The condition can be associated with chronic pulpal inflammation, and hence, adequate local anesthesia can be difficult to achieve. Inhalation sedation with additional supplemental anesthetic may decrease pain during dental treatment. The retention of dental restorations is a substantial problem and may necessitate pretreatment of the enamel with $5 \%$ sodium hypochlorite that removes the proteins encasing the hydroxyapatite crystals. Esthetic concerns are common, especially in cases involving the anterior teeth. Tooth loss can result from aggressive progression of caries. Some cases require the use of special management techniques for addressing dental fear and/or anxiety resulting from stories heard from parents or peers or from pain experienced during a previous dental visit. Inhalation sedation can be used to manage dental fear and anxiety during dental treatment. Other challenges that may arise include those related to quality of life, such as difficulties in treating children with no known previous dental visits, need for long and/or multiple appointments, need for missing school for some days, diminished oral health-related quality of life along with higher treatment costs as treatment done under general anesthesia. ${ }^{11,31-32}$

\section{TREATMENT MODALITIES}

Early identification and diagnosis of patients that are at risk for $\mathrm{MIH}$ can facilitate the provision of more effective treatments, better results, and reduced treatment costs. ${ }^{33,34}$ Many factors must be considered before deciding a specific treatment protocol, including the child's age, severity of the $\mathrm{MIH}$, restorability of tooth or teeth involved, presence or absence of pulpal involvement, presence of third molar germs, long-term prognosis, and cost of treatment. ${ }^{32}$ Administration of Local anesthesia is often challenging in children with $\mathrm{MIH}$, and it can be rendered more difficult to achieve because of chronic pulpal inflammation. The tooth could be highly sensitive to hot and cold temperatures..$^{35}$ As teeth affected by $\mathrm{MIH}$ could be more difficult to 
anesthetize, thereby the use of inhalation sedation $\left(\mathrm{N}_{2} \mathrm{O}\right)$ to increase the pain during dental treatment ${ }^{33,36,37}$ and use of supplemental anesthetic techniques, such as intraosseous, palatal, and/or intraligamental anesthesia have been suggested..$^{35,38}$

Articaine infiltration can be effective, and inferior alveolar nerve block adjunct with buccal articaine infiltration has been shown to be more effective. ${ }^{39}$ Rubber dam isolation and the application of saliva ejectors to replace high-volume suction can also be helpful in the management of teeth hypersensitivity. ${ }^{1}$ William, et al. ${ }^{33}$ have described useful approaches for the management of children with $\mathrm{MIH}$.

\section{Risk identification}

Assess caries risk and the patient's medical and dental history.

\section{Early diagnosis}

Examine the patient as early as possible, identify and assess molars at high risk of MIH via dental radiographs before eruption, and monitor those teeth during eruption.

\section{Remineralization and desensitization}

Emphasize the benefits associated with practicing adequate oral dental hygiene measures at home, including the use of fluoridated toothpaste and with the professional application of remineralizing agents as topical fluoride varnishes. Casein phosphopeptide-amorphous calcium phosphate can be helpful in reducing dental sensitivity, particularly in hypocalcified areas. . $^{33,40}$

\section{Prevent dental caries and post-eruptive breakdown}

Emphasize the importance of adequate oral hygiene strategies, desensitizing agents, reducing cariogenic habits, and professional application of pit and fissure sealants in the dental clinic. Remind child's parents that soft drinks generally contain considerable amounts of sugar $^{8}$ and hence, should be avoided.

\section{Restorations or extractions}

Esthetic concerns involving anterior teeth with $\mathrm{MIH}$ can be managed via different techniques, such as microabrasion and bleaching. Bleaching may be advisable in full-thickness brownishyellow or yellow defects, but not in whitish-cream or creamy-yellow defects that are located in inner part of the enamel. Resin infiltration may be more effective, especially in areas with shallow defects. ${ }^{33,40-43}$ However, defects involving the entire width of enamel may require conventional approaches, such as composite resin restorations, particularly if the carious process has involved one or more surfaces with using self-etching adhesive. Full coverage restorations, such as stainless-steel crowns are good options for teeth with severely damaged surfaces. The rates of failure and replacement of restorations are very high; thus, long-term follow-up is mandatory. ${ }^{33,40,44}$ Some authors have suggested the pretreatment of enamel with $5 \%$ sodium hypochlorite that removes protein encasing the hydroxyapatite crystals. ${ }^{45,46}$ The removal of remaining hypomineralized enamel before the placement of composite restorations has been recommended. $44,47,48$ Some restorative materials, such as glass ionomer cement (GIC) or resinmodified glass ionomer cement (RMGIC) are not recommended to be used in occlusal surfaces of hypomineralized molars (load-bearing areas), but can be used temporarily to reduce hypersensitivity (for 1 to 2 weeks), until a definitive restoration can be placed. They can be used in partially erupted teeth. ${ }^{49} \mathrm{GIC}$ restorations have various advantages, including easy placement, fluoride release, and chemical bonding properties. RMGIC restorations have similar advantages to GIC restorations, but are superior in terms of ease of handling, wear resistance, fracture toughness, and resistance..$^{50-52}$

If restoration of the tooth is impossible, and extraction is the only treatment option, early orthodontic assessment is recommended prior to extraction, with close monitoring of the development of the occlusion. ${ }^{53-56}$ Extraction may be the treatment of choice for non-restorable teeth or those with poor prognoses, but in very young children, occlusal guidance must be utilized to ensure that the second permanent molars move in position of the first molar. ${ }^{33,40,53-57}$ Many factors must be considered, especially in cases involving the mandibular arch. The optimal timing for extractions is evidently between the ages of 8 and 10 years. $^{55}$

Extractions should be performed after the eruption of the lateral incisor (age 7 years), but usually before eruption of the second permanent molar and the second premolar. Radiographs should be used to confirm that the second permanent molar is within the bone, and that calcification of the bifurcation area has commenced 55. If the extractions are performed too early, the second premolars can drift distally, particularly in the mandible, and the labial segments can retrocline, thus increasing the overjet. In addition, early extractions do not permit until to confirm the presence of third molar follicles prior to the commencement of the extractions. If the extractions are performed are delayed, the second 
premolar teeth may tip distally, and spaces between teeth might arise. In addition, occlusal forces can cause mesial tipping and rotation of the second molars.

The Angle's classification of occlusion must be determined prior to PFM extraction, and compensation or balancing may be required. In patients with Class I occlusion and minimal crowding, the maxillary and mandibular PFMs should be extracted at the optimal time, and compensatory extractions should be performed when extractions are restricted to the mandibular PFMs. ${ }^{55,56}$ In patients with Class I occlusion and moderate crowding, simultaneous extraction of both maxillary and mandibular PFMs should be performed at the optimal time, but crowding of the permanent teeth would require adequate management later. If bilateral buccal segment crowding is present, the balancing and compensatory extractions of maxillary PFMs may be required. In cases of labial crowding, delaying the PFM extraction until the eruption of permanent second molars should be considered, to facilitate the utilization of the extraction space for alignment with a fixed appliance. ${ }^{55,56}$ Class II malocclusion with minimal crowding is difficult to manage, and orthodontic consultation should be sought, ideally. The maxillary and mandibular PFMs should be extracted at an optimal time; however, crowding of the permanent teeth will require adequate management later. PFM extraction should be delayed, if possible, to facilitate utilization of the extraction space for correcting the incisor relationship via a fixed appliance, especially in the maxillary arch..$^{55,56}$ Class II malocclusion with moderate crowding is also difficult to manage, and orthodontic consultation should be sought. The maxillary and mandibular PFMs must be extracted at an optimal time, and the space obtained should be utilized immediately for the relief of crowding via treatment with fixed orthodontic appliances. ${ }^{55,56}$ Dental management of Class III malocclusion is challenging, and orthodontic consultation should be sought. Neither balancing nor compensatory extractions are generally recommended..$^{55}$ Treatment options are summarized (Table 5).

\begin{tabular}{|ll|}
\hline Table 5. Treatment options for molar and incisor hypomineralization. ${ }^{21,33,40-43,47,49,54-56}$ \\
\hline Anterior teeth & Treatment decisions are based on the severity of the condition: \\
& Resin perfusion \\
& Microabrasion \\
& Bleaching \\
& Resin Infiltration \\
& Resin composite restorations \\
& Composite veneers \\
Posterior teeth & Treatment decisions are based on the severity of the condition: \\
& Desensitizing toothpaste \\
& Fluoride varnish \\
& Sealants \\
& GIC or RMGIC as temporary restorations (1-2 weeks) to reduce tooth sensitivity \\
& Resin composite restorations \\
& Full-coverage restorations (for example, stainless steel crowns) \\
& Extraction
\end{tabular}

\section{Maintenance}

Long-term follow-up with close monitoring of the restoration margins is required to avoid posteruption breakdown. In the long term, full coronal coverage restorations should be considered. Patients who have undergone extractions must be closely monitored by an orthodontist.

MIH is frequently associated with permanent incisors and affects one or more first molars and is characterized by well demarcated opacities and qualitative defects of enamel caused by reduced inorganic enamel components, and reduced mineralization that can cause esthetic, functional, psychological, and behavioral problems in children. The prevalence of $\mathrm{MIH}$ is increasing. The causative mechanisms involved remain unclear, but they are thought to be multifactorial. Children who have systemic problems during the first three years of life or are born preterm and/ or children whose mothers have positive medical history during the pregnancy may develop $\mathrm{MIH}$. The dental management of children with $\mathrm{MIH}$ is more difficult and challenging for general dentists and pediatric dentists. The early diagnosis of children with $\mathrm{MIH}$ and monitoring their PFMs would provide better treatment results. More emphasis on oral hygiene strategies, prevention, 
and remineralization processes are required to reduce dental hypersensitivity.
The author would like to thank Deanship of Scientific Research at Majmaah University for supporting the work under Project Number No.R-2021-83.

\section{ACKNOWLEDGEMENTS}

Conflict of Interest: None.

\section{REFERENCES}

1. Almuallem Z, Busuttil-Naudi A. Molar incisor hypomineralisation (MIH) - an overview. Br Dent J. 2018 Oct 5;225:601-9. [Full Text]

2. Weerheijm KL. Molar incisor hypomineralization (MIH): clinical presentation, aetiology and management. Dent Update. 2004 Jan-Feb;31(1):9-12. [ubMed | Full Text | DOI]

3. Weerheijm KL, Duggal M, Mejare I, Papagiannoulis L, Koch G, Martens LC, et al. Judgement criteria for molar incisor hypomineralisation $(\mathrm{MIH})$ in epidemiologic studies: A summary of the European meeting on MIH held in Athens, 2003. Eur J Paediatr Dent. 2003 Sep;4(3):110-3. [PubMed | Full Text]

4. Jalevik B. Prevalence and diagnosis of molar-incisorhypomineralisation (mih): a systematic review. Eur Arch Paediatr Dent. 2010 Apr;11(2):59-64. [ubMed | Full Text | DOI]

5. Gomez TPM, Jimeno GF, Dalmau BLJ, Tarrida GL. Prevalence of molar-incisor hypomineralisation observed using transillumination in a group of children from Barcelona (Spain). Int J Paediatr Dent. 2012 Mar;22(2):100-9. [PubMed | Full Text | DOI]

6. Kilınc G, Cetin M, Kose B, Ellidokuz H. Prevalence, aetiology, and treatment of molar incisor hypomineralization in children living in Izmir City (Turkey). Int J Paediatr Dent. 2019 Nov;29(6):775-82. [Full Text | DOI]

7. Hubbard MJ. Molar hypomineralization: What is the US experience? J Am Dent Assoc. 2018 May;149(5):329-30. [PubMed | Full Text | DOI]

8. Shubha AB, Hegde S. Molar-Incisor Hypomineralization: Review of its prevalence, etiology, clinical appearance and management. Int J Oral Maxillofac Pathol. 2013;4(1):26-33. [Full Text]

9. Hussein AS, Ghanim AM, Abu-Hassan MI, Manton DJ. Knowledge, management and perceived barriers to treatment of molar-incisor hypomineralisation in general dental practitioners and dental nurses in Malaysia. Eur Arch Paediatr Dent. 2014 Oct;15(5):301-7. [PubMed | Full Text | DOI]

10. Silva MJ, Alhowaish L, Ghanim A, Manton DJ. Knowledge and attitudes regarding molar incisor hypomineralisation amongst Saudi Arabian dental practitioners and dental students. Eur Arch Paediatr Dent. 2016 Aug;17(4):215-22. [PubMed | Full Text | DOI]

11. Kalkani M, Balmer RC, Homer RM, Day PF, Duggal MS. Molar incisor hypomineralisation: experience and perceived challenges among dentists specialising in paediatric dentistry and a group of general dental practitioners in the UK. Eur Arch Paediatr Dent. 2016 Apr;17(2):81-8. [PubMed

\section{| Full Text | DOI]}

12. Crombie F, Manton D, Kilpatrick N. Aetiology of molar-incisor hypomineralization: a critical review. Int J

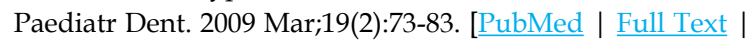
DOI]

13. Ahmadi R, Ramazani N, Nourinasab R. Molar incisor hypomineralization: a study of prevalence and etiology in a group of Iranian children. Iran J Pediatr. 2012 Jun;22(2):245-51. [PubMed | Full Text]

14. Lygidakis NA, Dimou G, Briseniou E. Molar-incisor-hypomineralisation (MIH). Retrospective clinical study in Greek children. I. Prevalence and defect characteristics. Eur Arch Paediatr Dent. 2008 Dec;9(4):200-6. [ubMed | Full Text | DOI]

15. Lygidakis NA, Dimou G, Marinou D. Molar-incisor-hypomineralisation $(\mathrm{MIH})$. A retrospective clinical study in Greek children. II. Possible medical aetiological factors. Eur Arch Paediatr Dent. 2008 Dec;9(4):207-17. [P $\underline{\text { PubMed | Full }}$ $\underline{\text { Text }}$ | DOI]

16. Beentjes VE, Weerheijm KL, Groen HJ. Factors involved in the aetiology of molar-incisor hypomineralisation (MIH). Eur J Paediatr Dent. 2002 Mar;3(1):9-13. [릴ed | Full Text]

17. Jeremias F, Koruyucu M, Kuchler EC, Bayram M, Tuna EB, Deeley K, et al. Genes expressed in dental enamel development are associated with molar-incisor hypomineralization. Arch Oral Biol. 2013 Oct;58(10):1434-42. [PubMed | Full Text | DOI]

18. Alaluusua S, Lukinmaa PL, Vartiainen T, Partanen $M$, Torppa J, Tuomisto J. Polychlorinated dibenzo-p-dioxins and dibenzofurans via mother's milk may cause developmental defects in the child's teeth. Environ Toxicol Pharmacol. 1996 May 15;1(3):193-7. [uuMed | Full Text | DOI]

19. Laisi S, Kiviranta H, Lukinmaa P-L, Vartiainen T, Alaluusua S. Molar-incisor-hypomineralisation and dioxins: new findings. Eur Arch Paediatr Dent. 2008 Dec;9(4):224-7. [PubMed | Full Text | DOI]

20. Laisi S, Kiviranta H, Lukinmaa PL, Vartiainen T, Alaluusua S. Molar-incisor-hypomineralisation and dioxins: new findings. Eur Arch Paediatr Dent. 2008 Dec;9(4):224-7. [PubMed | Full Text $\mid \underline{\text { DOI] }}$

21. Teixeira RJPB, Andrade NS, Queiroz LCC, Mendes FM, Moura MS, Moura LFAD, et al. Exploring the association between genetic and environmental factors and molar incisor hypomineralization: evidence from a twin study. Int J Paediatr Dent. 2018 Mar;28(2):198-206. [PubMed | Full Text I DOI]

22. Wright JT. Diagnosis and treatment of molar-incisor 
hypomineralization. In: Handbook of Clinical Techniques in Pediatric Dentistry [Internet]. 1st ed. Hoboken: John Wiley \& Sons, Inc; c2015 [cited 2021 Jan 21]. p. 99-106. Available from: https://books.google.com.np/books/about/ Handbook_of_Clinical_Techniques_in_Pedia.html?id=J8Z9BgAAQBAJ\&redir_esc $=y$. [ $[$ Full Text $]$

23. Steffen R, Kramer N, Bekes K. The Wurzburg MIH concept: the MIH treatment need index (MIH TNI): A new index to assess and plan treatment in patients with molar incisior hypomineralisation (MIH). Eur Arch Paediatr Dent. 2017 Oct;18(5):355-61. [PubMed | Full Text | DOI]

24. Aren G, Ozdemir D, Firatli S, Uygur C, Sepet E, Firatli E. Evaluation of oral and systemic manifestations in an amelogenesis imperfecta population. J Dent. 2003 Nov;31(8):585-91. [uuMed | Full Text | DOI]

25. Seow WK. Dental development in amelogenesis imperfecta: a controlled study. Pediatr Dent. 1995 Jan-Feb;17(1):26-30. [PubMed]

26. Yip HK, Smales RJ. Oral rehabilitation of young adults with amelogenesis imperfecta. Int J Prosthodont. 2003 Jul-Aug;16(4):345-9. [PubMed | Full Text]

27. Crawford PJM, Aldred M, Bloch-Zupan A. Amelogenesis imperfecta. Orphanet J Rare Dis. 2007 Apr 4;2:17. [PubMed | Full Text | DOI]

28. Levy SM, Broffitt B, Marshall TA, Eichenberger-Gilmore JM, Warren JJ. Associations between fluorosis of permanent incisors and fluoride intake from infant formula, other dietary sources and dentifrice during early childhood. J Am Dent Assoc. 2010 Oct;141(10):1190-201. [ $\underline{\text { PubMed | Full Text }}$ [ DOI]

29. Iida H, Kumar JV. The association between enamel fluorosis and dental caries in U.S. school children. J Am Dent Assoc. 2009 Jul;140(7):855-62. [PubMed | Full Text | DOI]

30. Skaare AB, Aas AM, Wang NJ. Enamel defects on permanent successors following luxation injuries to primary teeth and carers' experiences. Int J Paediatr Den. 2015 May;25(3):221-8. [PubMed | Full Text | DOI]

31. Singh A, Singh N, Srivastava M, Khan R, Kariya P, Abdullah A. Molar incisor hypomineralization: An update. J Med Radiol Pathol Surg. 2017;4(3):17-21. [Full Text]

32. Ghanim A, Silva MJ, Elfrink MEC, Lygidakis NA, Marino RJ, Weerheijm KL, et al. Molar incisor hypomineralisation (MIH) training manual for clinical field surveys and practice. Eur Arch Paediatr Dent. 2017 Aug;18(4):225-42. [ubMed | Full Text | DOI]

33. Lygidakis NA. Treatment modalities in children with teeth affected by molar-incisor enamel hypomineralisation (MIH): A systematic review. Eur Arch Paediatr Dent. 2010 Apr;11(2):65-74. [PubMed | Full Text | DOI]

34. William V, Messer LB, Burrow MF. Molar incisor hypomineralization: review and recommendations forclinical management. Pediatr Dent. 2006 May-Jun;28(3):224-32. [PubMed | Full Text]

35. Negre-Barber A, Montiel-Company JM, Boronat-Catala M, Catala-Pizarro M, Almerich-Silla JM. Hypomineralized second primary molars as predictor of molar incisor hypomineralization. Sci Rep. 2016 Aug;6:31929. [uㅏbMed | Full Text | DOI]

36. Discepolo KE, Baker S. Adjuncts to traditional local anesthesia techniques in instance of hypomineralized teeth. N Y State Dent J. 2011 Nov;77(6):22-7. [PubMed | Full Text]

37. Mathu-Muju K, Wright JT. Diagnosis and treatment of molar incisor hypomineralization. Compend Contin Educ Dent. 2006 Nov;27(11):604-10. [PubMed | Full Text]

38. Fayle SA. Molar incisor hypomineralisation: restorative management. Eur J Paediatr Dent. 2003 Sept;4(3):121-6. [PubMed | Full Text]

39. Jadhav GR, Mittal P. Anaesthesia techniques for maxillary molars - A questionnaire-based retrospective field survey of dentist in Western India. J Clin Diagn Res. 2016 Mar;10(3):ZC15-7. [PubMed | Full Text | DOI]

40. da Silva-Junior GP, de Almeida Souza LM, Groppo FC. Comparison of articaine and lidocaine for buccal infiltration after inferior alveolar nerve block for intraoperative pain control during impacted mandibular third molar surgery. Anesth Prog. 2017;64(2):80-4. [ubMed | Full Text | DOI]

41. Lygidakis NA, Wong F, Jalevik B, Vierrou A-M, Alaluusua $\mathrm{S}$, Espelid I. Best clinical practice guidance for clinicians dealing with children presenting with molar-incisor-hypomineralisation (MIH): An EAPD Policy Document. Eur Arch

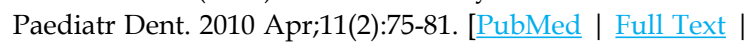
DOI]

42. FagrellTG, DietzW,JalevikB,NorenJG.Chemical, mechanical and morphological properties of hypomineralized enamel of permanent first molars. Acta Odontol Scand. 2010 Jul;68(4): 215-22. [ubMed | Full Text | DOI]

43. Anand V, Arumugam SB, Manoharan V, Kumar SA, Methippara JJ. Is resin infiltration a microinvasive approach to white lesions of calcified tooth structures? A systemic review. Int J Clin Pediatr Dent. 2019 Jan-Feb;12(1):53-8. [PubMed | Full Text | DOI]

44. Stenhagen K, Tveit A. Microabrasion to improve aesthetic. Vidensk Klin. 2016 May 26;120:890-7. [Full Text]

45. William V, Burrow MF, Palamara JEA, Messer LB. Microshear bond strength of resin composite to teeth affected by molar hypomineralization using 2 adhesive systems. Pediatr Dent. 2006 May-Jun;28(3):233-41. [PubMed]

46. Wright JT. The etch-bleach-seal technique for managing stained enamel defects in young permanent incisors. Pediatr Dent. 2002 May-Jun;24(3):249-52. [uㅏbMed]

47. Venezie RD, Vadiakas G, Christensen JR, Wright JT. Enamel pretreatment with sodium hypochlorite to enhance bonding in hypocalcified amelogenesis imperfecta: case report and SEM analysis. Pediatr Dent. 1994 Nov-Dec;16(6):433-6. [PubMed]

48. Lygidakis N, Chaliasou A, Siounas G. Evaluation of composite restorations in hypomineralised permanent molars: A four-year clinical study. Eur J Paediatr Dent. 2003 Sep;4(3):143-8. [ubMed]

49. Li RW. Adhesive solutions: report of a case using multiple adhesive techniques in the management of enamel hypoplasia. Dent Update. 1999 Sept;26(7):277-87. [PubMed 


\section{| Full Text $\mid \underline{\text { DOI] }}$}

50. Hansen EK. Dentin hypersensitivity treated with a fluoride-containing varnish or a light-cured glass-ionomer liner. Scand J Dent Res. 1992 Dec;100(6):305-9. [PubMed | Full Text | DOI]

51. Mahoney EK. The treatment of localised hypoplastic and hypomineralised defects in first permanent molars. N Z Dent J. 2001 Sept;97(429):101-5. [PubMed]

52. Berg JH. Glass ionomer cements. Pediatr Dent. 2002 Sept-Oct;24(5):430-8. [PubMed]

53. Croll TP, Nicholson JW. Glass ionomer cements in pediatric dentistry: review of the literature. Pediatr Dent. 2002 Sept-Oct;24(5):423-9. [PubMed]

54. Eichenberger M, Erb J, Zwahlen M, Schätzle M. The timing of extraction of non-restorable first permanent molars: a systematic review. Eur J Paediatr Dent. 2015 Dec;16(4):272-8.

\section{[PubMed]}

55. Abuhijleh E, Al Taki A, Varma S, Warreth A, Al Sharqi SM. Clinical practice guidelines: Guidelines for elective first permanent molar extraction. Acta Sci Dent. 2018 Nov;11(2):151-2. [Full Text]

56. Cobourne MT, Williams A, Harrison M. National clinical guidelines for the extraction of first permanent molars in children. Br Dent J. 2014 Dec 5;217(11):643-8. [라Med | Full $\underline{\text { Text }} \mid \underline{\mathrm{DOI}}$

57. Ashley P, Noar J. Interceptive extractions for first permanent molars: a clinical protocol. Br Dent J. 2019 Aug;227(3):192-5. [PubMed | Full Text | DOI]

58. Williams JK, Gowans AJ. Hypomineralised first permanent molars and the orthodontist. Eur J Paediatr Dent. 2003;4: 129-132. [ubMed | Full Text]

This work is licensed under a Creative Commons Attribution 4.0 International License. The images or other third party material in this article are included in the article's Creative Commons license, unless indicated otherwise in the credit line; if the material is not included under the Creative Commons license, users will need to obtain permission from the license holder to reproduce the material. To view a copy of this license, visit http://creativecommons.org/licenses/by/4.0/ 